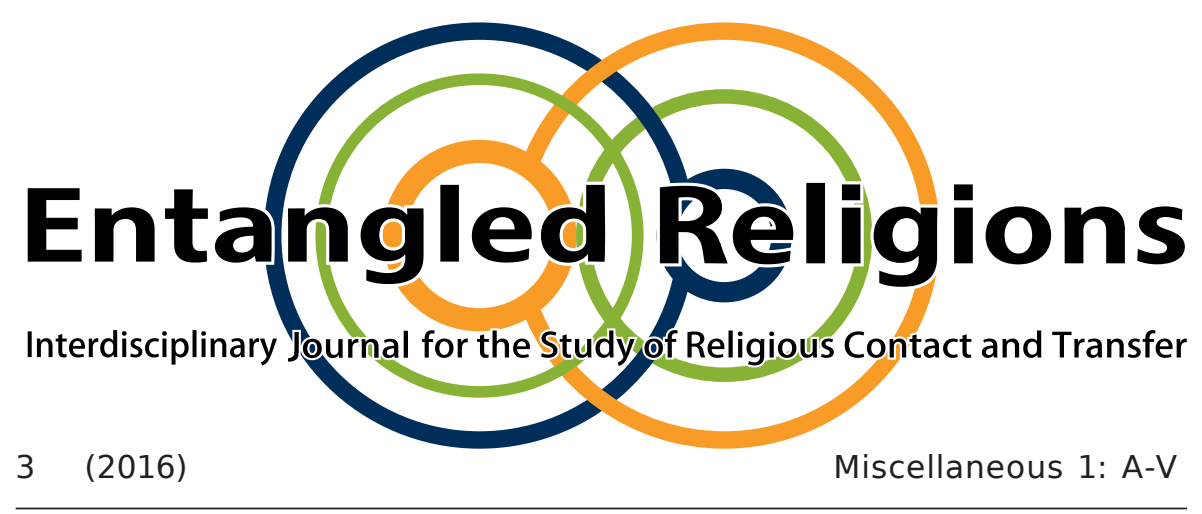

Proto-Indo-European Roots of the Vedic Aryans

TRAVIS D. WEBSTER

Center for Traditional Vedanta, USA

(C) 2016 Ruhr-Universität Bochum ISSN 2363-6696
Entangled Religions 3 (2016) http://dx.doi.org/10.13154/er.v3.2016.A-V

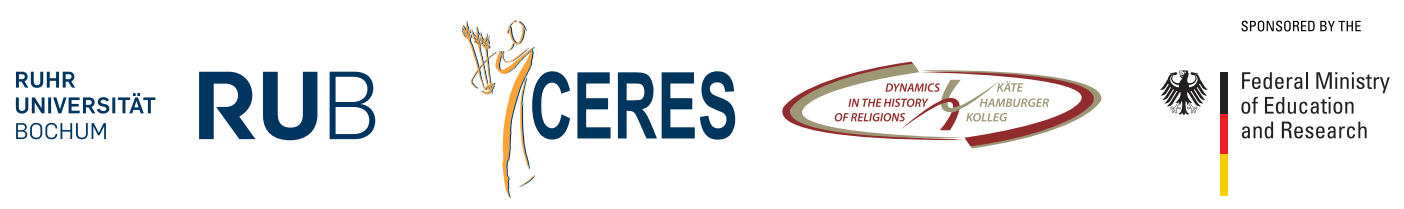




\title{
Proto-Indo-European Roots of the Vedic Aryans
}

\author{
TRAVIS D. WEBSTER \\ Center for Traditional Vedanta
}

\begin{abstract}
Recent archaeological evidence and the comparative method of Indo-European historical linguistics now make it possible to reconstruct the Aryan migrations into India, two separate diffusions of which merge with elements of Harappan religion in Asko Parpola's The Roots of Hinduism: The Early Aryans and the Indus Civilization (NY: Oxford University Press, 2015). This review of Parpola's work emphasizes the acculturation of Rigvedic and Atharvavedic traditions as represented in the depiction of Vedic rites and worship of Indra and the Aśvins (Nāsatya). After identifying archaeological cultures prior to the breakup of Proto-Indo-European linguistic unity and demarcating the two branches of the Proto-Aryan community, the role of the Vrātyas leads back to mutual encounters with the Iranian Dāsas.
\end{abstract}

KEY WORDS Asko Parpola; Aryan migrations; Vedic religion; Hinduism

\section{Introduction}

Despite the triumph of the world-religions paradigm from the late nineteenth century onwards, the fact remains that Indologists require more precise taxonomic nomenclature to make sense of their data. Although the Vedas are widely portrayed as the 'Hindu scriptures' and are indeed upheld as the sole arbiter of scriptural authority among Brahmins, for instance, the Vedic hymns actually play a very minor role in contemporary Indian religion. As a result, a number of classificatory schemes have emerged for distinguishing between 'Vedic religion' and the post-Vedic 'classical Hinduism' beginning around 400-200 BCE and represented by folk practices 
and Indian epics such as the Mahābhārata, Rāmāyaṇa, and the Purānas. ${ }^{1}$ Moreover, the Finnish Indologist Asko Parpola (2015) correctly reminds us that modern Hindu references to some grand religious system denoted by the Sanskrit phrase sanātana dharma, "eternal law or truth," finds no basis in any ancient texts (3). With one root stemming from the Indus civilization of the third millennium BCE and another planted alongside the Rigvedic migration to the subcontinent, Parpola's recent contribution to the study of Indian religion is grounded in a highly contentious field of linguistic, archaeological, and textual research.

One important feature of Parpola's work is his distinction between two separate waves of Proto-Indo-Aryan-speaking immigrants and more specifically the ways in which the Vedic literature fused with indigenous beliefs and forms of worship on the subcontinent. ${ }^{2}$ Focusing primarily on archaeological cultures and speech communities of the Early Bronze Age (c. 3300-2500), which descend from a single original language, or Ursprache, Parpola maintains "it is possible, through successive cultures with one ultimate origin, to trace the trail of the major branches of the IE language family to the areas where they are first historically attested" (50). Although the term 'ārya' is a tribal self-appellation found in the Vedas, for linguists the word Aryan (or Indo-Iranian) refers to a branch of languages that consist of Indo-Aryan and Iranian 'daughter languages,' all of which ultimately descend from a single Proto-Indo-European (PIE) speech community. Utilizing archaeo-linguistics and a genetic model to

1 For the French Indologist Louis Renou, "Aryan religion (that is, Indo-European on Indian soil)" refers to a "body of religious belief" brought to India by "Aryan tribes" during the second millennium BCE $(1961,16)$. Renou explains elsewhere that "the Upanishads take us to the very brink of Hinduism" $(1964,8)$.

2 Parpola, Asko. 2015. The Roots of Hinduism: The Early Aryans and the Indus Civilization. NY: Oxford University Press. 
account for the relations between languages of the Indo-European (IE) family, the different branches of which formed from a single original “linguistic community, which disintegrated suddenly, dispersing in different directions" (16), Parpola ultimately intends to link material culture of the ancient Eurasian steppes and Proto-Indo-Aryan speakers to the Vedic migration into India.

The hypothesis that all IE languages go back to a single language, namely Proto-Indo-European, is supported by the development of the Romance languages out of the Vulgar Latin spoken throughout the Roman Empire, but accounting for a hypothetical proto-language involves considerably more hurdles than explaining the descent of modern languages from a known Romance proto-language, which is itself but one member of an Italic branch of the IE language family. Grouping Aryan (i.e., Indo-Iranian), Greek, and Armenian languages as descendants of linguistic communities speaking variants of "Southeast IE," Parpola states that "the steppes east of the Dnieper River were probably the ancestral homeland of the IndoIranian speakers," and he further suggests "the ancestors of the Greeks and Armenians occupied the westernmost part of the Yamnaya continuum" (51-52). The genetic model and comparative reconstruction is rendered more complex by linguistic convergence and social interaction with nonIndo-European speakers, however, the breakup of IE languages could benefit from a more precise classification of the subgroups that remain implicit to Parpola's conceptualization of “Late PIE” (passim). 


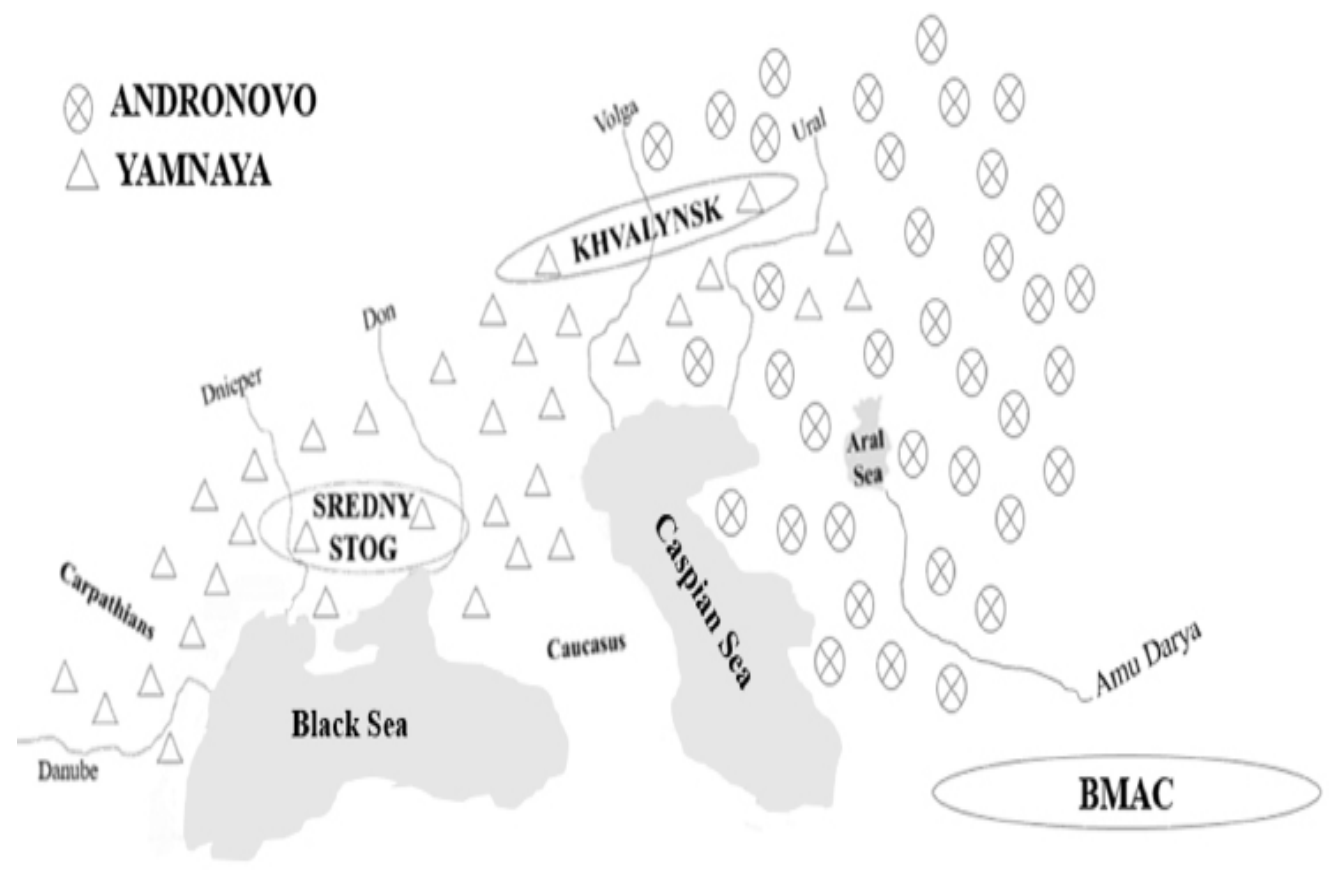

Map 1: Late Neolithic and Bronze Age Archaeological Cultures Image by Travis D. Webster

Most linguists estimate the age of PIE to be no less than about six thousand years and the original homeland, or Urheimat, is generally thought to be a narrowly defined area just north of the Black Sea (see Map 1) on the western side of the Eurasian steppes, a vast territory extending from the Carpathians east of the Danube River all the way to Manchuria. The Early PIE-speaking Sredny (or Srednij) Stog cultures (c. 4700-3400) which interacted with the westward expanding Late Neolithic Khvalynsk culture (c. 5000-3800 BCE) of the Volga steppes, and thrived between the Don and Dnieper rivers during the Copper Age, contributed in the mid-forth millennium to the formation of the Yamnaya cultural complex described by Parpola as the ancestral homeland of the Indo-Iranians. The most widely accepted hypothesis, however, is that the Yamnaya community is in fact the 
PIE homeland. Observing that the Yamnaya culture "certainly fits the bill of being the late Proto-Indo-Europeans," while expressing grave doubts about the prospect of the Yamnaya being "merely ancestral to the Indo-Iranians," Fortson suggests "it seems quite unlikely that anything specific enough to be identified as Indo-Iranian or pre-Indo-Iranian was already on the scene at that time." ${ }^{3}$ Parpola's way of dealing with this issue is persuasive.

The important point emphasized by Indo-Europeanists concerns the date for the earliest possible end of PIE linguistic unity, which is crucially related to PIE vocabulary associated with wheeled vehicles. Allowing a range of error of two to three centuries for carbon-14 dating, the earliest wheeled vehicles yet discovered were produced around 3500-3300 BCE. As numerous terms associated with their use can be reconstructed for LatePIE the invention of wheeled vehicles must have occurred before any of the future branches separated. Going further, Parpola points to the only known evidence for the discovery of wagons predating 3500 BCE-in the form of drinking cups complete with rotating wheels and ox foreparts-which were used by the Late Tripolye people (c. 4100-3400 BCE) who invented the wheeled vehicle C. 3600 BCE (43-45). The significance of this hypothesis lies with Parpola's claim that the Tripolye culture of Moldavia and Ukraine was taken over by Early PIE-speakers C. 4300-4000 BCE.

Arguing against Indo-Europeanists who locate the Late-PIE-speaking homeland in the Yamnaya cultural community of the Pontic-Caspian steppes, Parpola postulates the existence of Late PIE among the Late Tripolye people who were subdued by Early PIE-speaking Skelya pastoralists

3 Agreeing that a common PIE was probably no longer in existence by the end of the forth millennium, Fortson notes that "the area inhabited by the Sredny Stog has been seen by some as the 'real' PIE homeland;" around 3100-2900 BCE the Yamnaya cultural practices spread along the lower Danube and "with this we seem able to witness the beginnings of the Indo-Europeanization of Europe" (2004, 43-44). 
from the Sredny Stog culture. The infusion of "strongly hierarchical chieftainship" and "effective new leadership" purportedly "invigorated the Tripolye culture," although not without internal strife; Parpola speculates that this may have been the "age of warring heroes described in IE epic poetry" such as the Rigveda and the Iliad (38-39). Crucially, the Tripolye people were assimilated linguistically by c. 3600 BCE. During a final phase of differentiation we find that so-called Post-Tripolye cultures (c. 34002900 BCE) of the Pontic steppes had fused with the Late Sredny Stog II pastoralists, giving rise to the Yamnaya of southeastern Europe, or regional cultures which are "assumed to have spoken variants of 'Southeast IE,' which was still close to Late PIE" (47). Admitting that c. 3400 BCE PIE disintegrated suddenly, in all directions, Parpola explicitly locates this breakup with the Tripolye culture. Moreover, the Corded Ware cultures (c. 3100-2300 BCE) are associated with the rapid spread of tens of thousands of Post-Tripolye people moving throughout northwestern Europe in oxdrawn wagons.

Accepting the uncontroversial claim that Skelya pastoralists also invaded the Balkans during the last quarter of the fifth millennium, Parpola adds that as a result "their Early PIE eventually came to Anatolia" (49). While it is widely agreed that the extinct Anatolian group of languages was the first to split off from the PIE speech community there is little agreement about the status of Early PIE prior to the emergence of any other branches. A matter of ongoing importance for linguists is the fact that a number of common forms (e.g., the aorist, the subjunctive, and the dual) are strikingly absent from Anatolian, even though it is the only branch of IE languages to preserve consonantal reflexes of the laryngeals and other early phonological features. In this regard, it seems likely that Late PIE speech communities underwent further development before the emergence of Indo-Iranian, perhaps even as a result of local cultures of 
steppe origin. More importantly, since Vedic Sanskrit is distinguished by the phenomenon of laryngeal hiatus, in explaining the rapid spread of Late PIEspeaking Tripolye people to the Pontic-Caspian steppes, an area already occupied by Early PIE-speaking Skelya and Khvalynsk peoples, Parpola in fact appears to hint at a similar process: "the Early PIE substrata may have had an archaizing effect, leaving traces of laryngeal phonemes which were probably lost in the assumed Late PIE of the Tripolye area" (51). It is not until c. 2500 BCE that we get any significant dialectical differentiation for the split of Proto-Indo-Iranian and the origins of Indo-Aryan.

After identifying some Proto-Aryan loanwords borrowed by the Uralic (Finno-Ugric) languages, Parpola at one point goes so far as to suggest the name of the Aryan god Indra may be derived from a Proto-Uralic god of weather and war hero of Finnic epic poetry. Remaining focused on developments for the Indo-Aryan branch he explains that the powerful Sintashta culture (c. 2100-1800 BCE) arose when the Abashevo culture (c. 2300-1850 BCE) originating out of the eastern Late Yamnaya communities went on to occupy the Poltavka culture of the Volga-Urals (c. 25002100 BCE). The Proto-Indo-Aryan Sintashta culture seems to have been the first to use horse-drawn chariots (although controversial evidence points to a much earlier date for horseback riding) and along with its "daughter branch," the Petrovka culture (c. 2000-1800 BCE), gave rise to the extensive Andronovo cultural community (c. 2000-1450 BCE) which eventually extended to southern Central Asia (59). ${ }^{4}$ Subsequently, Parpola is able to bring fresh insight to the migrations of Vedic Aryans through Afghanistan and onwards to India. 


\section{Aryan Roots of the Vrātyas}

One of the more elusive groups among the Indo-Aryans is represented in the Atharvaveda, where they are known as 'Vrātyas'. The Vrātyas are perhaps most significant for Vedic religion due to the vrātyastoma purification ritual whereby they might be incorporated within the Brāhmaṇical community. The Vrātyas also preserved more archaic forms of Vedic ritual than those represented by the classical Brāhmaṇical traditions (Heesterman 1962). Along with the Dards and Nuristani, whose origins are similarly obscure, the Vrātyas were among the earliest group of Aryans to arrive in India from Central Asia, constituting what has been characterized as "one of the first pre-Vedic migration waves" (Kuz'mina 2007, 318-19). Even though the Brāhmaṇical concept of the 'Triple Veda' (i.e., the Rigveda, Sāmaveda, and Yajurveda) is not meant to exclude the Atharvaveda from the broader sphere of Vedic religion, Parpola's research centers on "a single phase in the acculturation of two different religions: 'Rigvedic' and 'Atharvavedic'” (130). To appreciate the important role of the Vrātyas in his characterization of Atharvavedic religion it is necessary to distinguish between the two branches of the Proto-Aryan community, which split c. 2300 BCE with the formation of the Abashevo culture.

Equating the Abashevo culture and the formation of the Sintashta culture of the southern Urals with "the departure of the Proto-Indo-Aryan branch," Parpola notes that "the Iranian branch remained in the Proto-Aryan homeland, the Pontic-Caspian steppes" (298). Moreover, Proto-Iranian speakers did not relocate to the Asiatic steppes until c. 1500 BCE when they likely adopted horse riding and spread in many directions. Distinctive pottery, terracotta figurines compared to Saka horsemen, and the probable practice of "sky" burial in southern Central Asia from c. 15000 to Hellenistic times more specifically connects "Proto-East-Iranian" or "Proto-Saka" to 
Yaz I-related cultures (c. 1500-1000 BCE) which followed the late phase of the Bactria and Margiana Archaeological Complex (BMAC, or the Oxus civilization), a Bronze Age civilization extending from the upper Amu Darya River to "the Indus Valley borderlands." (76) The formative phase of the BMAC (c. 3500-2500 BCE) includes Proto-Elamite and Early Harappan influence but due to significant archeological and linguistic evidence Parpola is "convinced that an early wave of Proto-Indo-Aryan speakers took charge of the BMAC around 2000 BCE" (ibid.). Recent excavations centered on this "urban phase" of the BMAC also include the remains of a chariot and cheek-plates identical to those used in the Sintashta culture.

Under new leadership BMAC people expanded to the Gorgan region in northern Iran and established trade relations as far west as Anatolia and Syria, where they are supposed to have assumed power over the local Hurrian rulers, but not before fusing with a "new wave" (298) of ProtoIndo-Aryan speakers and thereby including people who would form "hybrid Andronovo-BMAC cultures" in campsites throughout southern Central Asia C. 1700 BCE (ibid.). An archaeological correlate for the westward expansion is found in connection to the Early West Iranian Grey Ware C. 1500 BCE, which probably evolved from the Gorgan Grey Ware which represented a late phase of the Tepe Hissar culture (83). Characterized as such, the BMAC marks significant points in the history of Aryan migrations. The Hittite-Mitanni agreement which mentions the four Rigvedic gods Mitra, Varuṇa, Indra, and the Nāsatya (Āsvin) has been a major source for dating the Vedic period. Contributing to its collapse, on the other hand, steppe nomads representing late variants of the Andronovo cultures infiltrated the BMAC community around 1700 BCE. ${ }^{5}$ How do Proto-Indo-Aryan-speaking

5 For the classification and features of Andronovo sites see Kuz'mina (2007, 17-26). 
immigrants coming from the urban phase of the BMAC c. 2000-1700 BCE relate to later migrations c. 1400-1200 BCE?

In the most general sense, the "first wave" of Proto-Indo-Aryan speakers, that is, the first to have arrived at the BMAC from the PonticCaspian homelands and who occupied southern central Asia c. 2000 BCE, are described as "Aśvin worshippers," or the "Atharvaveda wave." The mature phase of the BMAC witnessed the introduction of both horses and camels (76). In the Mitanni kingdom of Syria, "the new Indo-Aryanspeaking rulers totally adjusted to the local culture" (85). Moreover, "the easy adoption of a new culture by an incoming powerful minority was also assumed in the case of the Late Tripolye culture" (298). Neither was the situation any different when Proto-Indo-Aryan speakers took over the $B M A C$ in the twentieth century BCE. The more crucial point requires a finer distinction for the relocation of Indo-Aryan speakers south of the Hindukush and the movement of BMAC people towards the Iranian plateau, and both groups are apparently related to the Gandhāra Grave cultures in the Swat Valley.

Now, although the Rigveda mentions about thirty tribes and clans only 'five peoples' wield significant influence over the main political formation of the early Vedic period: the Yadu, Turvaśa, Anu, and Druhyu tribes are thought to have entered India prior to the later migration of the Pūru tribe. Whereas other Indologists have long assumed as much (e.g., Witzel 1995), Parpola draws more specific conclusions about both the earliest Yadu tribe and the Pūru-Bharata tribal alliance. For instance, it is significant to note that "many of the Aśvin hymns of the Rigveda belong to the Kānva family of poets that was associated with the early Vedic tribe of Yadu, from which Kṛ̣nna's Yādava tribe is descended" (155). Kāṇva poets of the Rigveda resided in Gandhāra and burial customs, as well as proper names suggest connections with the Proto-Indo Aryans of Mitanni, who presumably 
came from the north Iranian branch of the BMAC (80-81; 120-21). During the following period, purportedly under the influence of late variants of the Andronovo cultures, cremation became predominant in the area of Gandhāra.

To reinforce his argument that the tribes of Pūru and Bharata entered South Asia c. 1400-1200 BCE Parpola focuses on identifying people known as Dāsa, Dasyu, and Paṇi and who are described as the enemies of the Rigvedic Aryans. Archaeological and linguistic evidence connects their Proto-Saka origins in northeastern Afghanistan to Yaz I-related cultures (c. 1500-1000 BCE) that replaced the BMAC in southern Central Asia during the Iron Age. Some Dāsa proper names recorded in the Rigveda and especially the Bharata king Divodāsa's eventual victory over Śambara further suggests that some Proto-East-Iranian speakers "survived the Proto-IndoAryan rule (c. 2000-1500 BCE) and were now part of the Saka community of the Dāsas, Dasyus, and Paṇis" (105). On the one hand, we know the Yaz I-related cultures extended westward and would later emerge, under the influence of West Iranian languages, as the Persians and Medians, but as Parpola suggests "the religion of the early Iranians of the Saka branch coming to Central Asia around 1500 BCE must surely have been much influenced by the Proto-Indo-Aryan religion prevailing there during their arrival" (106). On the other hand, while the Proto-Indo-Aryan rulers of Mitanni evidently knew of Indra (no doubt as a result of previous encounters with the Fedorovo Andronovan tribes), the Dāsa, Dasyu, and Paṇi peoples met with Indra's protégés (e.g., kings Divodāsa and Purukutsa) just west of the Hindukush.

After explaining that Divodāsa and Purukutsa led the Rigvedic Aryans into the Indus Valley, Parpola postulates a "fundamental religious difference between the waves of Proto-Indo-Aryan speakers who successively took over power in the BMAC" (109). Obviously, one such difference is the 
worship of Indra and indeed Parpola makes this explicit. Upon arriving in South Asia about 500 years later than the Atharvaveda wave, "the Rigvedic Aryans appear to have met Indo-Aryan speakers originating from the urban phase of the BMAC whose principal Aryan divinities were the Aśvins and Mitra-Varuna, but who had not previously known Indra" (302).

As noted above, many of the Rigvedic Aśvin hymns belonged to the Kāṇva family of poets associated with the Yadu tribe; moreover, the first half of Book 1 and Book 8 of the Rigveda consists of hymns revealed amongst the Kāṇva and Añgiras families. While most of the Rigvedic Aryans migrated further on to the plains, Parpola suggests the Indra-worshipping Atri clan (associated with Book 5 of the Rigveda) remained in Gandhāra and collaborated with the Kāṇvas in further developing some important Vedic rites. Probably somewhere in Central Asia the Rigvedic Aryans adopted the Ephedra based stimulant known as soma, which was the chosen drink of Indra. The Kāṇva clan, however, was accustomed to offerings of the honeybeer (madhu-surā) consumed by early PIE speakers: barley for Varuṇa and honey for the Aśvins. The incorporation of the Aśvins' gharma offering as a component of the soma sacrifice and "the Aśvins' obtaining a share of soma signal the Aśvins' submission to Indra" (121). We can assume this was a result of mutual encounters between the Atris and Kāṇvas in Gandhāra.

The incorporation of the Aśvins as part of the soma sacrifice, specifically as the 'head' or introductory pravargya rite, also finds archaeological correlates with the funerary 'face urns' of the Gandhāra Grave culture. In the personification of the soma sacrifice Vișnu, called the 'great hero' Mahāvīra, lies decapitated with only Dadhyañc Ātharvaṇa possessing the secret knowledge of restoring or 'reviving' the headless sacrifice. Indra threatens to behead Dadhyañc if he reveals this knowledge to anyone else, however, the Aśvins become pupils of Dadhyañc and agree to replace his head with a horse's head which, when cut off by Indra, will then be replaced 
by Dadhyañc's own head. Parpola notes that replacing a sage's head with a horse's head may have been an early part of the Proto-Indo-Aryan rites; a Potapovka related grave discovered in the Mid-Volga region of Russia and dated to c. 2100-1700 BCE features a human skeleton with the skull of a horse. Although the 'classical' Vedic ritual eventually preferred strangling the horse, the earliest references to the Vedic horse sacrifice in fact ordain its beheading. In the pravargya rite the ritual implements are placed on the ground in the shape of a man with the specially prepared gharma pot as the head. Parpola is able to make strong connections between characteristics of the pot (e.g., its protruding nose), the 'nose-birth' of the Aśvins, and rituals of the Aśvin-worshippers for whom these divine twins were now demoted as funerary gods.

For the early Proto-Indo-Aryans, Parpola explains, the Aśvins were dual kings similar to the Dorian Greek horse-riding Dioskouroi ("youths of Zeus") but distinguished by possessing the prestigious chariot. As a noble instrument of war and sport, around the end of the third millennium BCE the chariot quickly gave rise to the cult of the "deified chariot team" (109) More specifically, the Aśvins stood for the "divinized chariot-team, who were probably the highest gods representing their mundane counterparts" (ibid). Some Indo-Aryan names for the kings of Mitanni may also refer to Vedic chariotry, particularly the "charioteer" and the "chariot warrior," and with Parpola's suggested etymologies at least two are related to the adhvaryu and pratiprasthātar pair of sacrificial priests who later personify the Aśvins (88-89). With the development of the gharma/pravargya rite of the Aśvins, however, comes 'chanter priests' such as the 'highchanter' (udgātar) and others not mentioned in the Rigveda. Considering the "tradition of sāman singing in Aśvin rituals" among other things, Parpola suggests the Kāṇva and Añgirasa clans created the Sāmaveda in South Asia, but evidence suggests the Rigvedic Indo-Aryans encountered 
Angirases already in southern Central Asia (128-29). The origins of the Yajurveda, which introduces wish-fulfilling rites and whose principal priests are the adhvaryu and pratiprasthātar, are also located in the Atharvavedic worship of the Aśvins.

How does the Vedic religion of the early Aryan tribes relate to the later epics of classical Hinduism, and the continued dominance of Vaișnava cults throughout the subcontinent? The Indus civilization (c. 2600-1900 BCE) is a most likely source for the dominant non-Vedic elements of Hinduism. During the early third millennium BCE the Proto-Elamite civilization spread from the Persian Gulf across the Iranian plateau and southern Central Asia, and Parpola convincingly argues that much of the symbolism and iconic motifs of Proto-Elamite seals exerted significant influence on Harappan iconography. In such an environment, of course, it makes little sense to speak of 'indigenous' or Harappan culture without properly considering the broader impacts of urbanization in the ancient world. For instance, as a result of trade relations between Proto-Indo-Aryans of the BMAC and Assyrian merchants "the Aśvins were reduced to the role of saviors, divine medicine men, and funeral gods" (301). The Yādava clan, nevertheless, may have preserved elements of Vedic religion as late as C. 800 BCE, at which point the Megalithic culture is first attested in India; Parpola suggests the Vaișnava religion has a pre-Aśvin background connected to both Vedic myths and agricultural deities of Harappan religion.

The shift from Vedic religion to classical Hinduism, as represented by the dominant Vaișnava-Bhāgavata religion, is centered on a new set of divine brothers, that is, Bala-Rāma and Kṛ̦ṇa Vāsudeva of Mathurā, and is aided by the entrance of Iranian horsemen known as the Pāṇdavas. The Pāṇdavas were likely West Iranian speakers related to the Yaz II cultures (c. 1000-500 BCE) succeeded by the Medians and Persians (148-49). In the Mahābhārata the Pāṇdava warrior Arjuna has Kṛ̣ṇa as his charioteer, 
perhaps replacing the chariot team of the Aśvins. In this case Parpola may be correct in suggesting that the Pāṇdavas allied with Kṛṣna of Mathurā, who belonged to the Aśvin-worshipping Yãdava clan descended from Yadu, and that this alliance facilitated the extension of the Pāndava dynasty. More importantly, it was King Divodāsa's grandson (or son) the Bharata chieftan Sudās who fought in the famous 'Ten Kings' Battle' (dāśarājña) which allowed for the Bharata expansion into the Punjab.

Not only does the dāśarājña provide the Rigvedic prototype of the Mahābhārata but there are reasons to suggest that Sudās provided the "initial impetus" for compiling the earliest family books of the Rigveda, which initially existed as collections of hymns which were "the sole property of a few clans of poets and priests who were not willing to part with their ancestral and (more or less) secret knowledge" (Witzel 1995, 337). As such, I believe Parpola is fundamentally correct in rejecting characterizations of the Atharvaveda as "popular religion," a vague concept which nevertheless does not usually imply royal rituals, royally consecrated priests, or complex ritual manuals (130). Although some Kāṇvas and Añgirasas “appear to have joined the Indra-worshippers of the Rigvedic Aryans more or less immediately after the latter's entrance to South Asia," it appears that others "remained faithful to their original traditions" (302-03). The early Indra-worshipping converts include those who contributed to Books 1, 8, and 9 of the Rigveda, that is, the basis of the Sāmaveda, but the more faithful composed the Atharvaveda, which was also eventually incorporated into the Brāhmaṇical traditions. Characterizing the first Proto-Indo-Aryan migrations as 'pre-Vedic,' therefore, allows for erroneous conclusions.

Where Parpola probably contributes most is in excavating (linguistically, textually, and archaeologically) other Atharvaveda characters, namely the Vrātyas. Sometimes summarily dismissed as "prototypes of the Gypsies" (Basham 1989, 58) and often characterized by insipid traits, for example 
“orgiastic tendencies" (Eliade [1958] 1969, 105), the Vrātyas are among those itinerant Aryans for whom the paucity of evidence leaves much to the imagination. Similar figures include the Rigvedic (10.136) 'silent sages' (munis) and 'Iong-haired ascetics' (keśins) often postulated as early nonBrāhmaṇical prototypes of the Hindu yogins. While such groups thrived about a thousand years before Siddhārtha Gautama (fifth century BCE) some creative attempts to portray the Buddha as a founder-figure, similarly transcendent to the Brāhmaṇical impact of the Vedic Aryans, have focused on an ill-defined 'renouncer tradition' or the wider influence of Magadha as an opportunity to fabricate "non-Aryan precursors of later ascetics."6 Rather, the Aryan roots of the Vrātyas extend past the borderlands of Harappan religion. ${ }^{7}$

The Roots of Hinduism is divided in two parts, with a lengthy introduction (chapters 1-5) that makes explicit the major themes and parameters of the study and explains some basic concepts and methods of Indo-European historical linguistics; chapters 22-24 conclude with a summary of the book's

6 Consider the Sankrit term śramana, widely used to describe the 'ascetic community' in which Buddha sought enlightenment. In their Vedic usages both the verbal root 'śram' and its nominal derivative 'śrama,' which have the meaning of struggling, laboring, or striving towards some goal, occur often in the context of pious ascetics performing religious austerities (tapas) and yogic practices. Although seldom acknowledged, however, until around the time of the Buddhist king Aśoka (c. 268-232 BCE) Brāhmaṇical religion included renouncers, or 'those who strive' (śramaṇas). As Olivelle notes, whenever the term śramana is used in the earliest literature, either in an adjectival sense or as a noun denoting a category of individuals whose practice of austerities is particularly strenuous, it implies neither an opposition nor division between any classes or sectarian groups within the Brāhmanical tradition. Following inner conflicts around the time of Aśoka, usage of the compound word brāhmaṇaśramana signifies clear opposition between two distinct classes of people and perhaps śramaṇa can then mean a specifically non-Brāhmaṇical renouncer tradition (1993, 9-15).

7 Flood notes that the Vrātyas "spoke the same language as the vedic Aryans" but "lived on the edges of Aryan society" $(1996,79)$. In light of such generalizations it is important to emphasize that the tribal self-appellation "Aryan" is not to be confused with linguistic usage of the term to denote a branch of languages. Indeed, the Indian texts themselves do not agree about the extension of the term in reference to the "Iand of the Aryans" (āryāvarta). 
main findings and with additional speculations about the social structure of the Indus civilization and its possible influence on the later Brāhmaṇa texts. Part I, consisting of chapters $6-13$, is largely concerned with tracing the route of Aryan migrations to India by connecting shared features of Eurasian archaeological cultures to linguistic and ethnic groups of Central and South Asia. Part II includes eight chapters on the Indus civilization and its relation to West Asia. Of course, the Dravidian language family extends from the southernmost tip of India all the way to Brahui-speakers in Pakistan and is the most likely candidate for the Indus language; it is further suggested that contact with Proto-Elamite people of the Iranian plateau inspired Early Harappan cultures (c. 3200-2600 BCE) to create a writing system, the latest samples of which date to about 1800 BCE and are yet to be deciphered. Parpola's interpretation of 'religion in the Indus script,' at times highly speculative, is convincing on many accounts.

After providing archaeological and linguistic evidence to identify the Dāsas of the Rigveda with the Yaz I-related cultures, Parpola offers an etymology for the word Śambara to suggest a reference to the 'fortress' constructed by the primeval Iranian king Yima. Moreover, the Old Iranianspeaking Dāsas seem to have exerted significant influence on the earliest wave of Indo-Aryan immigrants in eastern India, away from the "Brahmins of the 'Aryan Midland,'" where the Vrātya religion flourished (262). Although "all Iranians worshiped Yima (Yama) in antiquity" this first man and king was particularly popular in Central Asia, where he "taught people to perform animal sacrifices similar to those of the Vedas" (Kuz'mina 2007, 190). Following earlier interpretations of the Rigvedic verse (10.124.5) where Indra offers the leading asura Varuna an opportunity to join the deities called devas, Parpola agrees that such a compromise between these two gods may have taken place: once in Central Asia and then again in the Indus Valley. Whereas the Aśvins initially represented their mundane 
counterparts (i.e., dual kings) upon arrival to the BMAC, their royal function was soon overtaken by Mitra (Mithra) and Asura Varuṇa (Ahura Mazdā); hence the Mitra-Varuna pair symbolizes the integral connection between the king and his royal priest (purohita) (109-16). For the earliest Proto-IndoAryan speaking immigrants in South Asia, Varuna became identified with the Harappan divine king. As a result of subsequent contacts and transfers, some important roles, traits, and functions absorbed by Varuna as well as other elements of Harappan religion were preserved in myths and rituals of the Atharvavedic tradition.

Correlations presented by Parpola's archaeo-linguistic approach to non-Aryan folk religions have serious implications for our understanding of the Brāhmaṇical tradition. Whereas the Vedic priests invited invisible gods to sit on the sacred grass next to the sacrificial fire, for instance, from Neolithic villages of Baluchistan and continuing into the Early and Mature Harappan periods we find thousands of terracotta figurines described as religious images, many of which were discovered in a private part of the homes in Mohenjo-daro: "thus the cult images were granted a special place comparable to the pūjā room or alcove in Hindu homes" (173). Tracing the etymology for the Sanskrit root pūj-, "to worship," to the Proto-Dravidian root *pūcu, "to smear, anoint," Parpola connects post-Vedic texts on Hindu image worship written by Brahmin priests to the smearing of unguents and various ointments on sacred objects from all over India (174). The continuation of other village practices remain speculative; the "dot or drop" (bindhu) smeared on the forehead might have Harappan roots in the adornment of terracotta figurines (278), or perhaps some Indus seals and tablets depicting crocodiles could relate to "crocodile gods" worshiped by tribes in Gujarat (182-86). Similar to previous Indological distinctions between 'hieratic' religion of the Brahmins and 'popular' religion of the Hindu masses, ironically, Parpola at times shifts between the fauna and 
flora of 'folk Hinduism' and elaborate Harappan cosmologies. With the aid of Harappan iconography and Hindu asterisms (nakșatras) he connects the origins of the cult of Durgā and Saakta Tantrism to the 'great rite' (mahāvrata) of the Vrātyas.

Indologists will be familiar with much of the data, texts, and sources of Parpola's narrative but we can still appreciate his efforts to bring this work to a wider audience. As Bruce Lincoln (1999) has shown, however, scholars themselves have been first and foremost in fabricating dubious 'Aryan homelands.' In this regard Parpola's study is particularly strengthened by explicitly ignoring "the impossible hypothesis that the Vedic Aryans were indigenous to South Asia" (92). Remaining undeterred by ideological subtexts surrounding the Urheimat, on the other hand, he demonstrates that it is now "possible to go quite far toward establishing the truth about the Indo-Aryan migrations" (9). Although many of his interpretations are entirely tentative Parpola's understanding of the Indus script and his visits to key archaeological sites of the recently discovered BMAC yield crucial observations. In light of such scholarly advances the time is no doubt ripe for reclassifying privileged narratives in world-religions discourse.

\section{Reference List}

Anthony, David W. 2007. The Horse, the Wheel, and Language: How Bronze-Age riders from the Eurasian steppes shaped the modern world. Princeton, NJ: Princeton University Press.

Basham, A.L. 1989. The Origins and Development of Classical Hinduism. Oxford: Oxford University Press. 
Eliade, Mircea. (1958) 1969. Yoga: Immortality and Freedom. Princeton: Princeton University Press.

Flood, Gavin. 1996. An introduction to Hinduism. Cambridge: Cambridge University Press.

Fortson, Benjamin W., IV. 2004. Indo-European Language and Culture. Oxford: Blackwell.

Heesterman, J.C. 1962. "Vrātya and sacrifice." Indo-Iranian Journal 6 (1): 1-37.

Kuz'mina, Elena E. 2007. The Origins of the Indo-Iranians, ed. J.P. Mallory. Leiden: Brill.

Lincoln, Bruce. 1999. Theorizing Myth: Narrative, Ideology, and Scholarship. Chicago: Univeristy of Chicago Press.

Olivelle, Patrick. 1993. The Āśrama System: The History and Hermeneutics of a Religious Institution. NY: Oxford University Press.

Parpola, Asko. 2015. The Roots of Hinduism: The Early Aryans and the Indus Civilization. NY: Oxford University Press.

Renou, Louis. (1953) 1968. Religions of Ancient India. New York: Schocken.

_-_. 1961. Hinduism. New York: Braziller. 
Witzel, Michael. 1995. "Rgvedic history: poets, chieftains, and polities." In The Indo-Aryans of Ancient South Asia: Language, Material Culture and Ethnicity, edited by G. Erdosy, 307-52. Berlin: Walter de Gruyter. 